\title{
The Influence of Local Context on the Games in Teaching English to Young Learners (TEYL) in Tongren (China)
}

\author{
Rong $\mathrm{Xie}^{1, *} \&$ Desheng Ding ${ }^{1}$ \\ ${ }^{1}$ The Department of Foreign Studies and Tourism, Tongren Preschool Education College, \\ Tongren, Guizhou, China \\ *Correspondence: The Department of Foreign Studies and Tourism, Tongren Preschool \\ Education College, Tongren 554300, Guizhou, China. E-mail: 274404162@qq.com
}

Received: March 28, 2017 Accepted: April 3, 2017 Published: May 28, 2017

doi:10.5296/ije.v9i2.10998 URL: https://doi.org/10.5296/ije.v9i2.10998

\begin{abstract}
With the economic globalization, English has become an international language. The young learners of community have shown the upsurge of learning English. The numerous of teaching methods are used by teachers, such as: Grammar -translation Method, Task-based Language Teaching Method, Games and so on. But the traditional method can not match the Ministry of Education. Then one of the most prevailing method is games in Primary school. But due to the influence of local context. There are many troubles and difficulties when the games are used in the process of teaching situations. This study through the analysis of the literature review and classroom observation why do the games fit for young learners and how many factors impact the games technique in teaching English to young learners. Finally, the factors of existence were identified, such as place, economy, time, teacher's belief and cognition and teacher' English proficiency level or knowledge and assessment materials and so forth. And put forward some recommendations for the future' English teaching.
\end{abstract}

Keywords: young learners; Primary school; games 


\section{Introduction}

\subsection{The Purpose of this Study}

Since 2011, ministry education has been aware of the emergency and necessity of carrying out a series of evolution in TEYL. Brief introduction Compulsory Education English Curriculum Standard (CEECS) in this section as the following points:

The new standards are designed to promote young learners' overall quality, such as interest, recognition, emotion, characteristic, physical and psychological. Cultivate multi-cultural awareness and critical thinking.

The framework of objectives of CEECS is language knowledge, language skills, learning strategies, affective factor. Language knowledge includes phonetic, intonations. Language skills include speaking and listening. Whereas learning strategies consist communication and cognition. Affective factor including International perspectives, patriotism, confidence, motivation, interest cooperation, team spirit and so on (Ministry of Education of the PRC, 2011, pp.1-27).

Teaching principles in TEYL include the principle of communication, the principle of the situation, aural-oral first and the principle of interest. YLs have naturally imaginative, with active and creative use of the second language in the classroom context. Young learners need to be offered plenty of opportunities to practice the second language. The teacher should be required creative appropriate situations according to YLs' competence and level to encourage their communication. YLs learn best when feeling happy, secure and relax. Teacher should give her/him more encourage rather than criticism. Encourage the use of both formative and summative assessment to evaluate YL's learning in the second language so that she/he can lay a good foundation for their further study. However. The numerous of teaching methods are used by teachers, such as: Grammar -translation Method, Task-based Language Teaching Method, Games and so on. But the traditional method can not match the Ministry of Education. Then one of the most prevailing method is games in Primary school. But due to the influence of local context. There are many troubles and difficulties when the games are used in the process of teaching situations. This study through the analysis of the literature review and classroom observation why do the games fit for young learners and how many factors impact the games technique in teaching English to young learners

\subsection{The Structure of This Study}

This study consists of six parts. The first part is the introduction identified my problematic issue in TEYL and told the reader the structure of this study. The second part is analyzed the national TEYL context and the local Tongren TEYL context in which I work. By analyzing the contextual factors that influence my TEYL and provides tentatively the reflection and information about the nature of the problem from different perspectives. The third part is a literature review relevant to features of YLs and the role of games, so that an attempt is made to critically analyze my issues in study. The fourth part is study methodologies and observation to tell the reader what actually happens in the Tongren context and whether/how is different from the features that I have identified above. The fifth part is analysis \& 
discussion to tell the reader why the differences exist referring back to what I have said about the Tongren context. The six part is conclusion.

\section{The National TEYL Context and Tongren TEYL Context}

\subsection{The National TEYL Context.}

\subsubsection{Unbalanced Development}

The development of coastal areas can be seen faster and more prosperous than that the western regions of China. Because country's economic development is not balanced which lead to teachers' teaching proficiency level is different, in terms of differences between developed areas and undeveloped areas. Cause serious shortage of English teachers in many areas.

\subsubsection{Teaching Materials}

However. Primary English textbooks have changed a lot and more close to YLs' life. A number of materials have improved greatly. Teachers' belief on teaching YLs have changed a lot with the revolution to take effect. But in the real context of China, there are still numerous unscientific test papers in the market which is used to evaluate learners' English proficiency level. The teachers did not make the syllabus clearly. A lot of problems and issues still have influenced the TEYL.

\subsubsection{Exam-oriented}

English is a compulsory subject for the entrance examination which accounts for 150 scores. Students, parents, schools pay a great attention to examination results, to expectations of the young learner is too high. She/He is expected to lay the foundation for junior high school in order that they do not lose at the starting line. To a large extent, teaching method is influenced by exam-oriented system.

Although primary schools do not require examinations, mainly emphasize the ability of students to listen and speak English. Whereas, most of test exercises are the mainly form of assessment which includes spell, fill-in, choose correct sentences and structures and so forth. These over-emphasis on testing at primary levels can have a heavily negative wash-back effect on what happens in the classroom and undermine attempts to introduce more experiential and activity based teaching(Moon, 2005. p33)

\subsection{The local Tongren TEYL Context in Which I Work}

This section provides an overview of a lot number of aspects of context that can affect TEYL.I introduce them all briefly here to illustrate the whole papers. TEYL is concerned with the teaching and learning of language and language is essentially human. People are central to any discussion of the context of TEYL. People's behavior is based on their changes in different time and different places. These conscious or unconscious "thinking" are influenced by the meaning that we have made of experiences we have had. I will analyze 


\section{I Macrothink}

three aspects from place, time, people how to influence the TEYL (Wedell and malderez,2013, p.15)

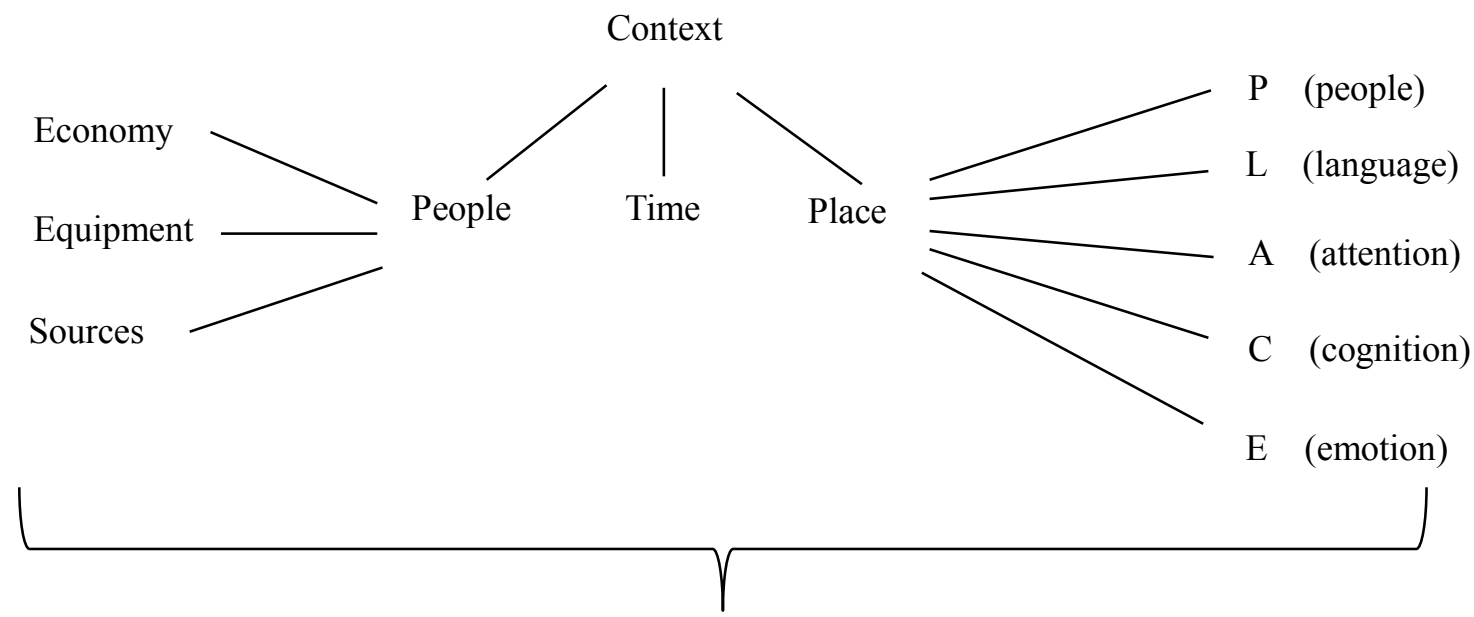

Attitudes to knowledge-Motivation_-belief — teaching approaches

The features of influence the education (Wedell and malderez, 2013, pp7-46)

\subsubsection{Place}

Tongren is located in the southwest of China, with an area of 18.000 square kilometers and the population of about 4.27 million. Ethnic minorities make up 75 percent of the whole population. So it belongs to an undeveloped area. The political, economic, cultural are lagging behind which to bring great challenges to education. The quality of education is largely influenced by three aspects of the facilities, resources and teachers.

Taking my own class as an example, there are 56 young learners who are crowded in a large classroom(size:17square). There aren't anything except for desks, benches, chalks, a blackboard, broom, trash cans and an old-fashioned TV set.

\subsubsection{Time}

Time is also one of the factors that affect the quality of English education. The overall amount of time given to the second language learning at primary level and how often children obtain lessons in a week are seen as important factors in determining the rate at which children acquire the language and the levels of language proficiency which they will finally reach (Met and Rhodes 1990.cited in Moon, 2005. p32). In our local context, children only receive approximately 40-60 hours' English course in a year, one class(contains 40minutes) per week.

\subsubsection{People}

A survey shows that among primary English teachers, few of them graduate as English majors and have bachelor's degree. Teacher have low English proficiency level and don't know much about the teaching strategies or theories to teach young learners. In addition, the government hasn't been sufficient money to provide their pre-service and in-service training. What's more, some teachers don't care about YLs' personality, physics and psychology 
development. Although the minority of them realized their weakness that they are not still willing to have a change and further study. Perhaps, they think that the knowledge they have hold is much more enough to teach YL. To a large extent, young teacher just follows the traditional approaches to teach YLs that as the same as their teachers once teach them when they were students in middle school, in high school or even in the University. One of the mistakes to learn English in order to get a high score to get into the place where have a good reputation secondary school.

\subsection{The Traditional English Teaching Approaches}

The major methods to teach YL in Tongren are mostly copies from foreign countries which are not suitable for Chinese YLs, now, there are many traditional methods which namely the Grammar-translation Methods, Task-basted Language Teaching and the Audio-lingual Method and so on, but the traditional teaching method to a great extent to be influenced by exam-oriented system which dominated in Tongren context. However, TEYL is influenced by the local context. The traditional ways of teaching English in our own local area still to memorize the new words, to repeat the text, to have a drill, to learn grammar and so on, students' interest in English is continuously decreasing. Under the influence of such a teaching situation, young learners are afraid of opening their mouth to speak English and even hate English classes in the boring or stiff atmosphere of the classroom. Although teacher has been aware of faultiness during the traditional methods in TEYL, they are not willing to have a change, some of them have a big change according to YLs characteristics and cognitive features, from easy to difficult. But there are long ways to go.

\subsection{The Current Popular English Teaching Approaches}

"Compulsory Education English Curriculum Standard" claims that TEYL need to be carried out different teaching approaches under the guidance of the second language acquisition or teaching theories (Ministry of Education of the PRC, 2011). The current popular English teaching approaches are communicative language teaching(CLT) and total physical response (TPR). CLT as an imported approach, was introduced in the 1970s in foreign language teaching (Richards and Rodgers,2001). "Communicative" refers to a particular view of language. It describes the purpose of language or principle function, as something used by human beings to communicate, by expressing and understanding interactional and transactional functions. It answers the two questions, "what is language for, what is language?"(Wedell and malderez,2013, p.101),which contains rhymes, dances, songs ,chants, performs and games rather than simply grammar and vocabulary alone in the field of TEYL. In a word, teachers use mix-techniques to teach YL that can establish her/his own teaching methodologies according to the theories and their own context. Game is one of the most effective techniques in CLT.

\subsection{This Thesis Emphasizes Games in Teaching English to Young Learners in Tongren (China)}

A result is obtained by contextual analysis which there is a preference and appropriate technique that is game. 
My personal view is that it is one of the most economical, most suitable and most well-rounded techniques among the numerous methods under my local context in Tongren. Games as solutions to large classes and limited resources. Therefore, this study emphasizes games in TEYL in Tongren.

\section{Literature Review}

\subsection{The Definitions of Game}

"Ludwig Wittgenstein was probably the first academic philosopher to address the definition of the word game. Wittgenstein claimed that the elements of games, such as a play, rules and competition all fail to adequately define what games are. But Thomas Hurka think that Wittgenstein was wrong.

Roger Caillois defined a game as an activity that must have the following characteristics: One of the features is separate which it is circumscribed in time and place. The second one is uncertainty which the outcome of the activity is unforeseeable. The third one is fun which the activity is chosen for its light-hearted character. The last one is non-productive which participation does not accomplish anything useful(https://en.wikipedia.org/wiki/Game).

Games were defined as "an activity with rules, a goal and element of fun" (Hadfield,1990). Along with the progress of the society and time pass by. Researchers put forward game has different definitions. "Compulsory Education English Curriculum Standard" defined a game as a good instruction which can help learner develop abilities and knowledge to learn. Game is activity with rules. Goals promote classroom which is dynamic, equality, voluntary and fun diving into the real world of TEYL (Ministry of Education of the PRC,2011).

\subsection{Features for Young Learners and the Role of Games}

In this part, the author mainly describes the relationship between the features for young learners and the role of the Games. Through previous researchers' theories analyze the relationship between the young learner and games. The purpose is to get a conclusion why games are thought to play an important role within TEYL.

\subsubsection{Instinct/Innate of Young Learner}

At any point in time, there is a "mental gap" to solve provide with the assistance of an "expert" who provides "scaffolding" and then internalizes the solution. Children learn through interpersonal activity, such as play with partners/teacher are created through interaction with more knowledgeable others. Vygotsky calls this gap -the Zone of Proximal Development (ZDP)(cited in Wedell,2016, handbooks).Young learner should be required /provided numerous materials and messages to stimulate to get ZDP.

From Piagetian viewpoint, the children's thinking develops as gradual growth of knowledge and intellectual skills towards a final stage of formal, logical thinking. Taking Piaget's view, YL becomes a very active period in her/his age, the environment should provide them a good opportunity to learn knowledge (cited in Simona,2015, pp773-776) 
YL is different from older children, adolescents or adults. According to them, they care more about the meaning than form. Even though they don't understand the individual words, learn from everything that surrounding them through intonation facial, expression, gesture and actions help to convey the meaning that they don' know (Harmer, 2007; Halliwell, 1992; Simona, 2015)

Linguists believe that the language system is instinct which stored in the brain, as long as people find the appropriate "trigger" to active it. Penfield \& roberts put forward that there is a "critical period" in language learning (age:2-13). Young learners are very easy to acquire language. Because she/he has a good memory. They are good at learning something by imitation. They dare to say anything come into their mind. They are not shy in expressing their thinking and emotion. They are curious and motivated to learn new language and easy acquisition standard pronunciation and intonation.

\subsubsection{The Role of Games Based on Instinct/Innate of Young Learner}

Countless skills that learners can develop through games in TEYL. Such as, listening, speaking, reading, writing, performing, singing, dancing, drawing. In addition, promote learner's critical thinking or creativity even more participate teamwork and good sportsmanship. Furthermore, many games reflect a variety of different stimuli and competence. Some of YLs might obtain reading the clues, and other learner remember hearing classmates call out the answer. In a word, games can provide a variety of sensory experiences and mode of thinking for YLs.

\section{2 .2 Short Attention Spans of Young Learner}

Attention is essential to learning. It is widely accepted that selective attention. Plays a major role in learning (Gass\&Selinker. 2008. p355).Scientific research has shown that children's attention span can maintain about 15 to 20 minutes in one class. But by observing my son obtain the evidence that if put children in the front of a TV with a favorite cartoon show on. He will stay a long time and enjoy the cartoon. So, the short attention span comes up only which we present stuff is useless, difficult or boring materials for them.

\subsubsection{The Role of Games under Short Attention Spans}

Games can grab YLs' attention during the activities, after hours of state-manded standardized teaching. I find my children are very tired and not any energy. Suddenly, an energetic game with lots of fun and movement surprise may be just what she/he needs.

\subsubsection{The Role of Games under the Curiosity of Young Learner}

Take my son as an example, it is often found that he asked all kinds of strange questions to adults, because he lack of experience that the new things in the world are curious to him. Teacher should seize this characteristic to design teaching activities. Curiosity is the greatest characteristic towards a child which all unknown things around him. This curiosity is fed by much information now available to them through the Internet and TV or people and so on. Game can be utilized in the language classroom. Via her/his natural curiosity to find out what they want (Shan,2010. p433-434) 


\subsubsection{Young Learner Give More Attention to Meaning Rather than Form}

Young learner is very different from teenagers and adults who are more interested in the language itself. If you observe children watching a film or listen to a story in English. They are trying to address what is going on or how is the result. They can get more response from people's faces, the place, people's gestures or intonation. YL don't pay attention to the words which are being used in the situation. On the contrary, adult maybe gives more attention their language is right or not.(Moon,2005,pp30-33)

\subsubsection{Young Children Learn Knowledge Through Activity and Experience}

Children have a strong instinct to explore everything, we can see the children like to touch and experience the real things, For example, switches, press buttons, use the ipad and the mobile phone. They don't have to follow the instructions, just by pressing or touching a button on the equipment which can searching for what her/his favorite children channel and materials, through the activities to provide cognitive development. Then, he has learned how to do it in the future. We can see that the activities they have been involved in support their understanding of knowledge. Language also has the same effect.

As an excellent YL English teacher, the purpose of learning English is communication, students need numerous practice to internalize important vocabulary and utterance, structures. We need to build a communication platform for learners.

\subsubsection{Games Provide a Context for Engaging in Practice Activity for Learner.}

Games are activities carried out by cooperating or competing decision makers, as a result seeking to achieve within a set of objectives and rules. It provides one way of helping learners to experience language rather than merely study it. (Wright ,2006)

\subsection{Affective Factors of Young Learner}

\subsubsection{Children's Affective is Changing Over Time.}

The concept of affective filtering was proposed by Dulay and Burt(1977) as "an internal processing system" to prevent learners from acquisition the language. Affective factors refer to feeling or emotion that individuals have something(Krashen,1983, p.31). Krashen in his affective filter hypothesis pointed out the second language acquisition is influenced by motivation, self-confidence and anxiety. His theory claimed that if the learner is in high or strong motivation, sufficient self-confidence and low anxiety, it is easy to acquire the second language. By contrary, if the learner is in demotivation, less self-confidence and high anxiety, it is difficult to learn and acquire L2.(Krashen,1983,pp31-141).From the theory can be seen performers with high motivation do better in SLA. Performers with a good self-image and self-confidence tend to do better in SLA. Low anxiety appears to be conductive to the SLA.

\subsubsection{Games Can Spur Motivation and Reduce the Stress in the Classroom}

It has a great advantage that YL can learn knowledge without knowing they are learning (Hadfield,1990). Because they don't dare to make mistakes in formal classroom, worry about teacher's criticism or peer' laugh. Whereas language is used by YL with a spontaneous and 
natural manner within games of the classroom. (Mubaslat,2012)

\subsubsection{Games Can Decrease Anxiety and Increase Self-Confidence}

Because so many YLs have so many assignments and subject to learn, even worry about failure of test or examination. Some of them worry about making a mistake when answering teacher's question lead to punishment and criticisim. So, games increase positive feeling and enhance self-confidence and self-esteem. (Sugar,2002. Cited in Simona 2015)

In summary, games contain a multi-functional role not only can promote children's body, mind, critical-thinking, wisdom and maturity but also to help with spontaneous to acquire and learning language in teaching English.

\section{Methodology}

\subsection{Procedures}

Firstly. I choose my own two classes (class1, Grade 4 and class two, Grade4) as comparative teaching in Tongren, Chuandong Private primary school in China. First of all. I have to explain why I choose these students. Because I have taught them since 2014.I believe YLs will feel at ease and more willing to talk with me. What's more, they have nearly the same English proficiency level to provide more effective data. Then, I want to explain why I would like to choose a foreign teacher rather than Chinese peer as an object of observation. Because, for one thing, foreign teacher without any English language obstacles, the phenomenon I observed that she always used the games to her English teaching. For another, she didn't know about the Tongren's context, she didn't know the management system of school, carried out instruction practice with her own idea and willing. Secondly. I invited foreign teacher to teach class 1 while class 2 was taught by myself, we used the same teaching materials in different periods. Thirdly. I observed the class of foreign teachers and recorded some information in the notebook, then, I invited foreign teacher to observe my class and give me some feedbacks or comments. Fourthly. I invited 10 students ( 5 people/per class) and foreign teacher to my house to have chat. Through the comparative of two classroom observation to get findings.

\subsection{Purpose}

What factors influence the game in TEYL?

Why do these affect factors exist?

Course introduction: "Let's eat" of Unit 5 of primary English. The content is to learn new words include: cake, hamburger, hot dog, chicken, bread, french fries, structure: I like...., Show me your ...., Pass me the ..., Total time (40 minutes) 


\section{1) Macrothink}

\subsection{Results}

Table 1. Classroom observation of class 1 and class 2

\begin{tabular}{|c|c|c|}
\hline item & Class 2 & Class 1 \\
\hline English teacher & Miss Xie & Miss Mary \\
\hline Teacher's image & $\begin{array}{l}\text { young, serious, seldom } \\
\text { smiles }\end{array}$ & $\begin{array}{l}\text { friendly, enthusiasm, always } \\
\text { smile, sufficient confidence, } \\
\text { beauty }\end{array}$ \\
\hline activities & $\begin{array}{l}\text { singing, reading, reciting, } \\
\text { repeating, writing, few } \\
\text { games, TPR, }\end{array}$ & $\begin{array}{l}\text { Singing, dancing, playing, doing } \\
\text { TPR, put all kinds of Games into } \\
\text { the whole class, performance }\end{array}$ \\
\hline praise & less often & often \\
\hline criticism & once & none \\
\hline student modality & $\begin{array}{l}\text { passive, less confidence, } \\
\text { demotivation, strong anxiety }\end{array}$ & $\begin{array}{l}\text { active, sufficient confidence, } \\
\text { higher motivation, low anxiety }\end{array}$ \\
\hline atmosphere & noisy, nervous & $\begin{array}{l}\text { active, relaxed, happy, dynamic, } \\
\text { enjoyable, exciting, curious, fun }\end{array}$ \\
\hline language, method & $\begin{array}{l}\text { English and Chinese, } \\
\text { GTM,TBLT,TPR }\end{array}$ & English, CLT,TPR \\
\hline $\begin{array}{l}\text { Teacher's } \\
\text { proficiency level }\end{array}$ & non-standard pronunciation & $\begin{array}{l}\text { knowledgeable, standard } \\
\text { pronunciation }\end{array}$ \\
\hline Participate & a few participate & the whole participate \\
\hline $\begin{array}{l}\text { Teaching situation } \\
\text { second language }\end{array}$ & $\begin{array}{l}\text { unreal/a little real } \\
\text { learning }\end{array}$ & $\begin{array}{l}\text { real, authentic } \\
\text { acquire }\end{array}$ \\
\hline Learner's thinking & control & un-control \\
\hline $\begin{array}{l}\text { Teaching } \\
\text { procedure }\end{array}$ & fragmented & coherent \\
\hline
\end{tabular}

\subsection{Feedbacks}

The questions for students are as follows:

Q1: Do you like playing games in English classroom?

Q2: Do you think the games can help you learn English?

Q3: Do you think the games can strengthen self-confidence/motivation and reduce the anxiety?

Q4: Do you think the games can contribute to the exam successfully?

Q5: Do you like your English teacher? Why?

When I asked the Q1, all of them answered yes. When I asked the Q2, half of the students from class 1 answered yes. Three of them from class 2 answered I don't know. The left two thought playing games just for fun, couldn't help to learn English. When I asked the Q3, all 
the students agreed that the games can decrease anxiety, increase self-confidence / motivation. When I asked the Q4, five of them answered yes, three students answered if we often use games in teaching, it can improve our oral English, but we can't finish the exercise and can't get high score in English exam. because so many fill-in the blanks need us to memorize the words and the sentences, playing games is waste of the time, no enough time to learn English. When I asked the Q5, most of them think if teacher is active, humorous, enthusiastic, friendly, we will like him/her.

The questions for foreign teacher are as follows:

Q1: What obstacles will encounter in the implementation of games?

One of the biggest obstacles is different levels the students possess. Perhaps, the high level learner have finished the games, while the low level learner still explored the rules of the games. The other one is large class, she responded with smile, so many students are crowded in a small classroom, it's difficult problem to ask them to do activities, especially fat kids. Games need plenty of room to activity. She pointed out the limited time is also a huge obstacle, because we can't finish the whole tasks in the limited time. When I asked her how do you treat the young learner's test, she indicated that the children should not have written exercises/test, but can carry out simple verbal test.

What she said above is what I want to say, It's common recognized evidence through the communication with the colleagues in the past. However, so few data could not explain the big problem, it was used to show some phenomena.

\section{Discussion}

\subsection{The Similarity on the Games between Class 1 and Class 2}

We can easily see that the classroom observation that I have described above some are the same as the national curriculum and literature review. Under the National Primary English curriculum standard required, English classroom must be interesting to YLs. The purpose of learning English is to communicate with the other. Make sure that learners are supported sufficient opportunities to practice language. With Mary's and my own lesson obviously presented, for example, we have carried out "games" as warming up, which is a good way to create a good atmosphere and develop learner's intelligence. In addition, a wide variety of games were implied in Mary's class. From my own class step 3 and Mary' class step 1---step 6. Which are the typical features of the games. The classroom behaviours obviously carry out games characteristics. The purpose of the class is based on curriculum and theories of literature review. On the one hand, games can foster classroom activity and fun. On the other hand, games can provide a real world which makes learner acquire language with spontaneity. This point we can see Mary asked learners to get a ticket goes to Macdonald eats for free. The enthusiasm of the learners was mobilized at once. Including Mary' step 2 students can't wait to open the box in order to take out their favourite food. At the moment, their emotional state is expected, curious, happy, imaginative which all of these match the characteristics of young 
children. Including my own class of "guess game and slow motion" are also welcomed by the majority of YLs. Students are willing to work together with his/her peers to use the language to give them happiness. From Mary's last step "memory game" which I observed that the language just now students had to learn were consolidated and restated in relaxed and meaningful situation. Memory game reflected child's memory which has the attention span feature in theory. Therefore we can conclude that the game is trustworthy and applicative. Everything has two sides, although it has countless advantages. We will also observe many problems during the classroom practice. We can also find that there are differences between classroom practice and national curriculum or literature theories. It will be described in the next step.

\subsection{The Differences between Classroom Practice and National Curriculum or Literature Theories}

\subsubsection{Games are not Really Reflect Language Learning}

As a result of Mary's comment to my teaching at the some extent game did not really reflect to transpire students' critical thinking and target language learning. From step3 guess game of my own classroom observation, we can see I still applied to some difficult task towards YL. Perhaps they simply don't understand the rules of games. So I have to explain the rules of the game in Chinese. Therefor there is no role to create the real language context. In their view, the game is just for fun.

From Figure 1 we can see my class is too serious. On the contrary, Mary's class is enthusiasm. Martin Wedell claimed that teacher as a person we do not need to be too formal. Use language in a friendly and casual way to connect with the learner. Simple language can be used to express abstract ideas (Wedell,2016, handbook)

\subsubsection{Games are Replaced by Traditional Methods}

Taking my own teaching material as an example. In step 3 presentations, grammar-translation instead of communication language teaching and Total Physical Response. What's wore. I often use the mother tongue to explain the difficulties points in TEYL. Most of the time the learners were required to memorize the new words. Repeat the utterance, recite the text, drill the grammatical structure by mechanical.

\subsubsection{Learners' Individual Levels Instead of the Overall Level}

Any other outstanding problem is that if one of Yls mastered the knowledge means instead of all of him/her learned too. As students have different levels cause part of them cannot immediately keep up with the pace of the teacher.

\subsubsection{Games Content Instead of Learning Content}

The minority of young learner English teacher believe that the games are through the songs, performances, stories, games, finger exercises to fill the whole classroom. The classroom has a good atmosphere on the surface, but ignores the second language acquisition. As mentioned in the literature. We must know the purpose of the games is used to help learners acquire 
English.

\subsection{What Factor Caused These Differences on Games in TEYL?}

\subsubsection{Different English Proficiency Level}

As far as I know, about 70 percent of learners are from rural areas where never engaged an English training. They have learned English from grades three. But 20 percent of learners are still participating in English training at the moment. 10 percent of them have involved in English training at their 5years old. These part of learners' English level are slightly higher than the other students.

\subsubsection{Lack of Funding}

Funding is contributing to a source of high quality education. One of the factors in Tongren context is a large class.56 children are crowded in a large classroom (about 17 square). Games of TEYL need to be provided a big activity space to learners and teachers. In addition. Advanced audio-visual equipment can help active classroom atmosphere. Computer can offer nearly new or advanced ideas and theories at home and abroad to teachers.

Even though some classrooms have slide projectors which it exists difficult to operate because of bad -quality machine.

Moreover, if the teacher does not have enough salary support their family, he will not settle his/her heart down to work.I remember one time with a few closed colleagues get together to have chat, They complained that so low pay(about 3 thousands yuan, RMB) per month ,perhaps it's a good choice to open the beauty salon, which can make more money to raise the old parents and young children .Two of them have opened English training institutions in local city centre for two years, which have a good student sources, can earn at least 10 million(RMB)a month, at once, everyone felt surprised, Wow! Wow!

\subsubsection{Lack of Time}

As I said in section 2 Tongren contexts, we have only one English class (40min) per week. Too less time to acquire L2 for children. In addition, the relevant administration of the school stipulated that educator must complete the whole contents of the textbook at the end of semester. The teacher has to grasp every minute to catch up with the pace. If we can't finish the teaching task, we will be criticized by the leadership, Even the teacher will be criticized in the front of the whole colleagues at the meeting. What's worse, discount his/her salary 50 percent of annual performance.

Teacher can't finish her/his teaching tasks in limited time. They may think games are just for fun and useless and without any practical meaning and they even regard playing games as a waste of time.

Teacher will arrange the class time to teach but no time for children to play games. Meanwhile, to put a game or into an English class is not an easy thing with the time limitation and curriculum shortage. It's hard for teachers to arrange a proper game into class. In addition, overload works make teachers boring and tired which lead to without enough 
time to prepare their course.

\subsubsection{The Imperfection of Assessment Materials}

Students' exercise-books, test-papers include a lot of spelling words, writing words, making sentences, writing dialogue, writing etc. YL try them best to remember every words or structure sentences in order to perfect finish his/her assignments to obtain teachers or parents' recognition and reward, they must complete the workbook with high score and correct mark, how to get high scores? Must memorize words, phrases, sentences, articles to get a high score, this extracurricular inappropriate materials inadvertently affect the intention of English learning. Inadvertently also impact the teacher's teaching. Teacher must apply to traditional method to satisfy what the students need. Gradually, this phenomenon will become a vicious circle.

\subsubsection{Teacher's Belief}

Teacher's belief was proposed in the context above. Most of the teachers are lazy, they do not want to spend more thought to consider their English teaching. In other words, they may not know how to change their English teaching, even do not know why to make a change.

\subsubsection{Lack Quality Teacher}

Taking my experience as an example, private primary schools in terms of shortage of teachers. Need our college' teachers to help them overcome obstacles. Sometimes, I really don't understand how to teach YL, even the approaches were used to teach college students which were applied to teach my young learners.

\subsection{What the Effects Would Be Caused If These Difficulties Can't Be Disposed Successfully?}

Over time, these differences will become a vicious circle, Firstly is to dampen the enthusiasm of young children to learn English, to combat their confidence to learn English, namely, young learners form a kind of the shadow in their heart toward the fear of learning English. Secondly, more games in English teaching will be failed and do not play a substantive role, do not reflect the real meaning of the game activities, did not complete the corresponding teaching tasks, do not improve the child's English skills. What's more, these factors will influence the primary school children's English development, and junior high school English development, and even the future development of English

\subsection{Suggestions}

\subsubsection{Funding}

First of all, the government should continuously provide sufficient funding to support teachers to join the re-service and in-service training, so as to improve teachers' teaching skill. Next, policy should take a good measure to increase the scale of construction, implement small class teaching as soon as possible. Once more, the government should increase the salary of teachers to improve the status of teachers. E nhance their motivation to teach. What's more, the department of education needs to carry out effective policy to make private school children to get the same education as the public school. Similarly, the government can 
also implement the Western Volunteer Program, because most of the teachers often lack of willingness to teach in rural areas in Tongren.

\subsubsection{The Role of the Policy Maker}

Policy makers can consult to arrange classes for TEYL as much as possible. In addition, policy maker should weaken the exam-oriented of primary school, crack down assessment materials which are not standardized on the market. Similarly, The administration section of the school should not pay attention to form, but should pay attention to the cultivation of students' communicative competence in English. Reduce over-load curriculum tasks.

\subsubsection{Teacher's Literacy}

Young learner English Teacher (YLET) should have had a rich knowledge of the culture and fluency in English.

YLET should know about knowledge of YLs' foreign language learning and appropriate teaching strategies for TEYL.

YLET should know knowledge/understanding of children's overall development

YLET should know YLs' foreign pedagogy and knowledge of children's foreign language learning for TEYL.

YLET need very good English language skills and a rich knowledge of the culture in order to get children interest. Because the children's thinking is open active and creative.it is possible exposure outside the classroom.

Teacher should update the concept of education access to advance with the time, love children and friendly to children. Teachers are arranged realistic workloads. (Moon, 2005, p33. Garton \& Copland and Burns, 2011, p.16)

\section{Conclusion}

Games as a technique of CLT, namely, the most prevailing approach in my local context is CLT. From the classroom observation revealed that games as a prevailing technique in TEYL. The result of this study further shows that although a great majority of teachers /learners favorite the effectiveness of using games in TEYL. But we do not use games as frequently as expected. But. The majority of young teachers possessed basic knowledge of games in TEYL. In terms of they understand about National English Curriculum Standards to Young Learners was not sufficient. Although most of them are interested in applying games that had a positive attitude. They did not fully implement it due to various reasons in my teaching context. This assignment illustrates some of the problems that exist in my context regarding the use of games in the classroom. The cause of existence is the factor of place, economy, time, teacher's belief and cognition and teacher' English proficiency level, assessment materials and so forth. Games are influenced by implementer in the local context. As a final word, how to properly use games to realize better games class still needs further research. 


\section{Acknowledgement}

The research is financed by Research on Humanities and social sciences of Guizhou Provincial Department of Education. Project No.: 2016ZC137. Young project. The title of the project: On Games in Teaching English to Young learners. Thanks for Prof. Martin gave me so much valuable suggestions about the article. In addition, I'm grateful to my families who supported enough time and energies for me to write this paper. Many thanks to them.

\section{References}

Garton, S., Copland, F., \& Burns, A. (2011). Investigating Global Practices in Teaching English to Young Learners. Aston University. Birmingham. British Council.pp.16.

Gass, S.M., \& Selinker, L. (2008). Second Language Acquisition. Routledge: Taylor\& Francis.

Hadfield, J. (1990). Intermediate Communication Games. Thomas Nelson and Sons Ltd.

Krashen, D. (1983). Principles and practice in second language. Oxford: Pergamon Press. pp.31-141.

Ministry of Education, P.R.C. (2011). Compulsory education English Curriculum Standard. Beijing Normal University Press. PP.1-23.

Moon, J. (2005). Teaching English to Young Learners: the challenges and the benefits. In English. British Council. pp.30-33.

Mubaslat, M.M. (2012). The Effect of Using Educational Games on the Student's Achievement in English Language for the Primary Stage. Retrieved from: http://files.eric .ed.gov/fulltext/Ed529467.pdf

Richards, J.C., \& Rodgers, T.S. (2001). Approaches and methods in language teaching. Cambridge: Cambridge University press. https://doi.org/10.1017/CBO9780511667305

Simona, L.F. (2015). The Effects of Using Games for English as a Second Language Primary School Learners. Discourse as a Form of Multiculturalism in Literature and Communication. Section: Language and Discourse. ARHIPELAG XXI PRESS. pp773-776.

Wedell, M. (2016). Approaches and Contexts in 5991. Handbook.

Wedell, M., \& Malderez, A. (2013). Understanding Language Classroom Contexts: The starting point for change. London: Bloomsbury. pp7-46/p101.

Wright, A. (2006). Games for Language Learning. Cambridge University Press. https://doi.org/10.1017/CBO9780511667145 


\section{Copyright Disclaimer}

Copyright for this article is retained by the author(s), with first publication rights granted to the journal.

This is an open-access article distributed under the terms and conditions of the Creative Commons Attribution license (http://creativecommons.org/licenses/by/3.0/). 